\title{
Anti-Semitism, Anti-Marxism, and Technophobia: The Fourth Volume of Martin Heidegger's Black Notebooks (1942-1948)
}

\section{Christian Fuchs}

University of Westminster: Communication and Media Research Institute (CAMRI), London, UK, christian.fuchs@uti.at, http://fuchs.uti.at

\begin{abstract}
The fourth volume of Martin Heidegger's Schwarze Hefte (Black Notebooks) was published in March 2015. It contains philosophical notes written in the years 1942-1948. This contribution discusses the role of anti-Semitism, the hatred of modernity, democracy, Marxism and socialism, the belittlement of the Nazi system, and the opposition to modern media and technologies that can be found in the book. It also provides English translations of some of the book's key passages.
\end{abstract}

Keywords: Martin Heidegger, anti-Semitism, Black Notebooks, Schwarze Hefte, philosophy of technology, media philosophy, Nazi ideology, National Socialism, media and communication studies, Nazi Germany, Nationalsozialistische Deutsche Arbeiterpartei (NSDAP).

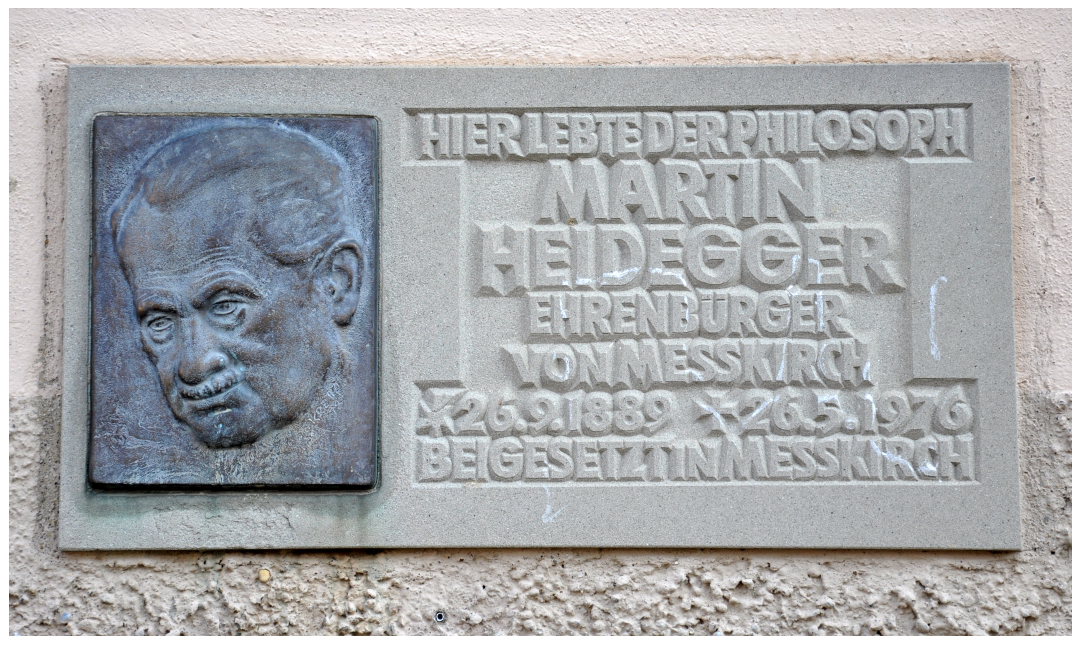

Image source:

By: Andreas Praefcke (Own work (own photograph))

[CC BY 3.0 (http://creativecommons.org/licenses/by/3.0)], via Wikimedia Commons

\section{Introduction}

The fourth volume of Martin Heidegger's (2015) Schwarze Hefte (Black Notebooks) was published in March 2015. It contains philosophical notes written in the years 1942-1948. In 2014, the first three volumes, covering the years 1931-1941, were released. Their antiSemitic passages have resulted in a sustained public debate. Heidegger in them wrote, for example, that Jews have a marked talent for calculation or that "world Jewry" means the uprooting of all being. The editor of the Black Notebooks Peter Trawny $(2014,11)$ says in his book Heidegger und der Mythos der jüdischen Weltverschwörung (Heidegger and the Myth of Jewish World Conspiracy) that such quotes are characteristic for Heidegger's ontohistorical anti-Semitism and his imagination of a Jewish world conspiracy.

According to Trawny $(2014,43)$, Heidegger in the Black Notebooks makes a connection between modern technology, calculating reason, and Jews. Trawny calls for a "revision of the engagement with Heidegger's thinking" (117). Such a revision has already started: In light of the Black Notebooks, Günter Figal stepped down from his position as president of the Heidegger Society. He says that he thinks the philosophical future is "the end of 
Heideggerianism"1. The University of Freiburg has considered abolishing Heidegger's former chair by rededicating of from a full professorship in phenomenology to a junior professorship in logic and linguistic analysis. ${ }^{2}$ Is the fourth volume a continuation of or a break with the thinking that can be found in the first three books?

Heidegger starts one of the now published notebooks (Anmerkungen $V$ ) with a quote by Leibniz: "Qui me non nisi editis novit, non novit" (325)—"He who knows me by my published works alone does not know me at all". The Black Notebooks are not a regular publication, but contain private philosophical notes that Heidegger wanted to have released as the final volumes of his collected works. The quote is an indication that he thought that one cannot know his thought without knowledge of the Notebooks and that he therefore considered their publication as important in order to give a more complete picture of his thought.

\section{Deutschtümelei}

The book shows Heidegger's deep disappointment by University of Freiburg's decision in January 1946 to revoke his license to teach. He saw this verdict as a betrayal of philosophy and thinking as such, and a betrayal of the German people (see: Heidegger 2015, 71, 79-80, 83-85, 87, 96-97).

All of the following are among the phenomena that Heidegger in the Black Notebooks' fourth volume sees negatively and as expression of what he called the machinations (Machenschaften) and the forgetfulness of being (Seinsvergessenheit): abstract art, America, anthropology, anti-fascism, Asia, Christianity, cultural philosophers, democracy, directors, existentialism, film, Georges Braques, Great Britain, historians, Jean-Paul Sartre, journalism, Juan Gris, Jews, Karl Jaspers, Karl Marx, magazines, mathematics, modern technology, museums, news, novels, Pablo Picasso, philology, psychology, radio, records, researchers, Russia, socialism, surrealism, television, tractors.

The few phenomena that he, in contrast, discusses positively taken together are an expression of Deutschtümelei (German jingoist ideology): Adalbert Stifter, Bauer (=farmer, but also builder/creator in German), customs, Ernst Jünger, fatherland, forests, Friedrich Hölderlin, Friedrich Nietzsche, German language, handwriting, heroism, homeland, hut, keeping silent, Meister Eckhart, Oswald Spengler, peasantry, poetry, South West Germany, teachers.

\section{Anti-Semitism and the Hatred of Modernity, Technology, and Socialism}

Heidegger says that Jewry is the principle of destruction, means self-destruction of history, that Marx is an expression of this principle because he saw spirit and culture as superstructure, and that it is bidden to combat the Jewish:

The anti-Christ must like every anti- stem from the same essential ground like that against which it is anti--hence like 'the Christ'. It stems from Jewry that in the age of the Christian Occident, i.e. the age of metaphysics, is the principle of destruction. The destructive lies in the reversal of the completion of metaphysics-i.e. in the reversal of Hegel by Marx. Spirit and culture become the superstructure of 'life'-i.e. the economy, i.e. the organisation-i.e. the biological-i.e. the 'Volk'. If only the by essence 'Jewish' fights in the metaphysical sense against the Jewish, the peak of history's self-destruction is reached; given that the 'Jewish' has everywhere seized domination completely, so the combat against 'the Jewish' becomes above all bidden in it ${ }^{3}(20)$.

\footnotetext{
${ }^{1}$ German original: „Das Ende des Heideggerianertums“. In: Interview mit Günter Figal. Badische Zeitung, January 23, 2015. http://www.badische-zeitung.de/literatur-und-vortraege/das-ende-des-heideggerianertums, accessed on March 1, 2015.

${ }^{2}$ Streit um Heidegger-Lehrstuhl. Martin? Edmund! FAZ Online. February 27, 2015. http://www.faz.net/aktuell/feuilleton/streit-um-heidegger-lehrstuhl-martin-edmund-13452086.html

${ }^{3}$ German original: „Der Anti-christ muß wie jedes Anti- aus dem selben Wesensgrund stammen wie das, wogegen es anti- ist-also wie ,der Christ'. Dieser stammt aus der Judenschaft. Diese ist im Zeitraum des christlichen Abendlandes, d.h der Metaphysik, das Prinzip der Zerstörung. Das Zerstörerische in der Umkehrung der Vollendung der Metaphysik—d.h. Hegels durch Marx. Der Geist und die Kultur wird zum Überbau des ,Lebens'-d.h. der Wirtschaft, d.h. der Organisation—d.h. des Biologischen—d.h. des ,Volkes'.
} 
This anti-Semitism and anti-socialism that opposes and equates Marx, materialism, and Jewry, is substantiated by an anti-socialist remark noted in 1946/1947: "Socialism is the peacelessness of humanity arranged as society in modernity, created by the technological civilisation"4 (238). Heidegger here further adds technology as a negatively perceived force and equates modern technology and socialism.

\section{The Belittlement of the Nazi System}

Heidegger belittles the Nazi system by arguing that the allied forces' occupation, collaboration of the Germans with the allied forces after 1945, or what he describes as modernity's nihilism would be worse than the horrors of the Nazi regime:

- He argues against an abstract nihilism that would be worse than concentration camps: "The terror of the ultimate nihilism is still scarier than all massiveness of the hangman's assistants and the concentration camps"5 (59). With the term nihilism Heidegger refers to the "momentarily political world constellation"6 (59).

- "The Germans now stand in the shadowing (Beschattung) by its own betrayal of its own essence directed against themselves-a process that must not refer to the inevitable consequences of the disappeared system's terror regiment-rather a behaviour that is blinder with rage (blindwütiger) and more destructive than the widely visible devastation and the horrors depicted on posters" ${ }^{\prime 7}$ (84-85). The editor remarks in a footnote that Heidegger likely here refers to posters the allied forces put up in Germany after the end of the war that showed images from the Nazi extermination camps with the headline: "These infamous actions: Your fault!" 8 (84, footnote 45).

- "How miserable this helpless truckling to the shadowing by the planetary terror of the world public is, compared to which the massive brutality of the historyless 'National Socialism' is the pure harmlessness-despite the highly visible palpability of the havoc that it cowreaked"9 (87).

Wenn erst das wesenhaft ,Jüdische' im metaphysischen Sinne gegen das Jüdische kämpft, ist der Höhepunkt der Selbstvernichtung in der Geschichte erreicht; gesetzt, daß das ,Jüdische' überall die Herrschaft vollständig an sich gerissen hat, so daß auch die Bekämpfung ,des Jüdischen' und sie zuvörderst in die Botmäßigkeit zu ihm gelangt" (20).

„Sozialismus ist die durch technische Zivilisation erzeugte Friedlosigkeit des zur Gesellschaft eingerichteten Menschentums der Neuzeit" (238).

5 "Der Terror des endgültigen Nihilismus ist noch unheimlicher als alle Massivität der Henkerknechte und der Kz".

6 "augenblickliche politische Weltkonstellation“.

${ }^{7}$ „Die Deutschen stehen jetzt in der Beschattung durch die eigene gegen sich selbst betriebene Verräterei am eigenen Wesen-ein Vorgang, der sich nicht auf unvermeidliche Folgen des Terrorregiments des verschwundenen Systems berufen darf-ein Verhalten vielmehr, das blindwütiger ist und zerstörerischer als die weithin sichtbare Verwüstung und die in Plakaten anschaulich zu machenden Greuel“ (84-85). Heidegger uses the German term Beschattung (that can best be translated as shadowing) instead of Besatzung (occupation). It has two different connotations: a) surveillance and b) casting a shadow on someone. The he employs this word indicates his negative view of Germany's occupation by the Americans, the British, the French, and the Russians, which neglects that it was the necessary consequence of the liberation from the Nazi system that was a German project oriented on anti-Semitism, fascism, racism, anti-democracy, anti-Marxism, social Darwinism, nationalism, imperialism, and leadership cult.

8 „Diese Schandtaten: Eure Schuld!”. For an example, see: http://www.hdg.de/lemo/bestand/objekt/plakat-schande-schuld.html.

9 „Wie erbärmlich ist dies ratlose Kriechen unter der Beschattung durch den planetarischen Terror einer Weltöffentlichkeit, mit dem verglichen die massive Brutalität des geschichtslosen ,Nationalsozialismus' die reine Harmlosigkeit ist-trotz der unübersehbaren Handgreiflichkeit der von ihm mitangerichteten Verwüstung?" (87). 
- "Wouldn't for example the misjudgement of this Geschick ${ }^{10}$-that did not belong to ourselves, wouldn't the suppression of the world's want (Weltwollen)-be an even more substantial 'guilt' and a 'collective guilt', whose extent could not even in essence be measured in the horrors auf the 'gas chambers'-more sinister than all publicly 'denounced' 'crimes'-that of course in the future nobody may excuse. Does 'one' have an idea that already now the German people and country are a single concentration camp-one that 'the world' certainly has never 'seen' before and that 'the world' also does not want to seethis not-wanting is even more wanting than our absence of will (Willenlosigkeit) against National Socialism" ${ }^{11}(99-100)$.

Heidegger in 1946 criticises that the Nazi regime despised the spirit (209), but in the same year says that 1933, the year Hitler came to power, was the attempt of "overcoming metaphysics"12 (147) and the "opportunity for a possible total consciousness (Gesamtbesinnung) of the Occident"13 (174). He also writes that one "everywhere only sees 'victims', although maybe the preconditions of victims may have been missing"14 (136).

Heidegger relativises and denies the singularity of the Nazi systems' horrors by drawing comparisons and arguing that after 1945 something even more horrific was happening in Germany. He argues that the German collaboration with the allied forces after the end of the war, the world public's denunciation of the Germans, and the allied forces' occupation after their liberation of Germany from the Nazi system are worse than the Nazi system and its crimes.

In the so-called 1986 "Historians' Dispute" (Historikerstreit), German intellectuals discussed the question of the singularity or non-singularity of the Nazi systems' crime. It among others involved contributions by the German philosopher and historian Ernst Nolte, who during the Nazi time was a student of Heidegger, and the philosopher Jürgen Habermas. Nolte argued for a revised historical account of Nazi Germany, including that one should consider the thesis for discussion that the president of the Zionist Organization Chaim Weizmann's 1939 statement that the "Jews in around the world fight in this war on England's side" ${ }^{15}$ may substantiate the hypothesis that "Hitler was allowed to treat the German Jews as prisoners of war and to detain them"16 (in: Augstein et al. 1987, 24). He also formulated that Auschwitz was not primarily driven by anti-Semitism, but was a reaction to the Russian Revolution: "Auschwitz does not primarily result from a traditional anti-Semitism and was at its core not a pure 'genocide', but it was first and foremost a fear-born reaction to the Russian Revolution's

\footnotetext{
${ }^{10}$ The German term Geschick means skill, but is also related to the terms Schicksal (destiny, fate) and schicken (sending). In Being and Time, Heidegger (2010) defines Geschick as "the occurrence of the community of a people (Volk)" (366) and "occurrence of Dasein in being-with-others" (368). He however also speaks of "the vicissitudes" (Geschicke) of questioning (19). Heidegger in Über den Humanismus (Letter on Humanism) writes: "Das Sein hat sich dem Denken schon zugeschickt. Das Sein ist als das Geschick des Denkens" (Heidegger 1949, 55)_-"Being has already sent itself to thinking. Being is as the destiny of thinking". Here Heidegger uses the terms Geschick and schicken/zugeschickt in the same context. Given the polysemy of the word "Geschick", it may be best to leave it untranslated.

11 „Wäre z.B. die Verkennung dieses Geschicks—das uns ja nicht selbst gehörte, wäre das Niederhalten im Weltwollen-nicht eine noch wesentlichere ,Schuld' und eine ,Kollektivschuld', deren Größe gar nicht-im Wesen nicht einmal am Greuelhaften der ,Gaskammern' gemessen werden könnte; eine Schuld—unheimlicher denn alle öffentlich ,anprangerbaren' ,Verbrechen'-die gewiß künftig keiner je entschuldigen dürfte. Ahnt ,man', daß jetzt schon das deutsche Volk und Land ein einziges $K z$ ist-wie es ,die Welt' allerdings noch nie ,gesehen' hat und das ,die Welt' auch nicht sehen will-dieses Nicht-wollen noch wollender als unsere Willenlosigkeit gegen die Verwilderung des Nationalsozialismus" (99-100).

12 „Überwindung der Metaphysik“.

13 "Gelegenheit einer möglichen Gesamtbesinnung des Abendlandes".

14 ",überall nur ,Opfer' sieht, wo vielleicht die Voraussetzung zum Opfer fehlte“.

15 "German original: „nach der die Juden in aller Welt in diesen Krieg auf der Seite Englands kämpfen würden”.

${ }^{16}$ German original: „daß Hitler die deutschen Juden als als Kriegsgefangene (a) behandeln und d.h. internieren durfte".
} 
extermination processes"17 (in: Augstein et al. 1987, 32). "Wasn't the Bolshevists' 'class murder' the logical and factual prius of the Nazis' 'racial murder'?"18 (in: Augstein et al. 1987, 45).

Jürgen Habermas argued that Nolte belittled the Nazis' crimes and that he "denies the Nazi crimes' singularity"19 (in: Augstein 1987, 97). "The Nazi crimes lose their singularity when they are at least vulgarised as response to (today enduring) Bolshevist extermination threats. Auschwitz shrinks then to the format of a technological innovation and is explained by the 'Asian' threat posed by an enemy that still stands in front of our doors"20 (71).

Assuming a singularity of Auschwitz and the Nazi system stresses the moral and political guilt of the Nazis and the Nazi system. Comparing this system, trying to causally explain it as a reaction to something external, or arguing that something much more horrific happened before or after in history therefore excuses the Nazi system. According to Habermas, Nolte justified the Nazi system and its crimes by denying their singularity and causally reducing it to a reaction to Bolshevism. Both Nolte's assumptions and some of Heidegger's arguments in the Black Notebooks' fourth volume share the denial of the singularity of the Nazi system and of the immanent causes of this system of extermination. Heidegger relativises the Nazi system by expressing the opinion that after 1945 something much more horrible took place in Germany.

Nolte was not just a student of Heidegger during the Nazi time, but also defends him against the criticism that his works reflect Nazi ideology. Nolte (1988), for example, stands up for Heidegger in a review of Victor Fárias' (1989) book Heidegger and Nazism. Fárias convincingly argues that Heidegger's thoughts were "nourished in traditions of authoritarianism, anti-semitism, and ultranationalism" (Fáris 1989, 4). Nolte (1988) says Farías' book is "only a symptomatic product of that denunciation literature that at the present time booms in many fields" ${ }^{21}(108)$ and that it opposes "the whole German and European tradition in so far as it is not 'enlightened' in the author's understanding"22 (113). Heidegger and Nolte are both not just representatives of right-wing ideology in politics and philosophy, but also seem to share the view that the Germans are the true victims in the $20^{\text {th }}$ century's history.

Heidegger in the Black Notebooks' fourth volume shows little sympathy for the Nazis' victims, but a lot of mourning about what he describes as the attempted destruction of the Germans and their culture. He, in 1946, speaks of "a world shame (Weltschande) that threatens the German people"23 (146), of a "killing machinery that has now been set in motion in Germany"24 (148), that the logic of the atom bomb has the same logic as a "killing machinery that is set on the Germans" 25 (151). In 1948, he voices the same view by saying that there is a project "to wipe out the Germans spiritually and historically. One should not fool oneself. An old spirit of revenge goes round the Earth" ${ }^{26}(444-445)$. Heidegger's ideology is clearly antidemocratic when he writes for example in 1946/1947: "The anti-fascists are the lowest slaves

\footnotetext{
17 German original: „Auschwitz resultiert nicht in erster Linie aus einem überlieferten Antisemitismus und war im Kern nicht ein bloßer ,Völkermord', sondern es handelte sich vor allem um die Angst geborene Reaktion auf die Vernichtungsvorgänge der Russischen Revolution“.

${ }^{18}$ German original: „War nicht der ,Klassenmord' der Bolschewiki das logische und faktische Prius des ,Rassenmords' der Nationalsozialisten?".

${ }^{19}$ German original: „Nolte die Singularität der NS-Verbrechen leugnet“.

${ }^{20}$ German original: „Die Nazi-Verbrechen verlieren ihre Singularität dadurch, daß sie als Antwort auf (heute fortdauernde) bolschewistische Vernichtungsdrohungen mindestens verständlich gemacht werden. Auschwitz schrumpft auf das Format einer technischen Innovation und erklärt sich aus der ,asiatischen' Bedrohung durch einen Feind, der immer noch vor unseren Toren steht“.

${ }^{21}$ German original: „es ist lediglich ein symptomatisches Produkt jener Denunziationsliteratur, die gegenwärtig wieder auf vielen Gebieten Konjunktur hat”.

${ }^{22}$ German original: „Der eigentliche Zielpunkt der Anklageschrift von Farías ist nicht der Mensch und Philosoph Heidegger, sondern die ganze deutsche und europäische Tradition, soweit sie nicht im Sinne des Verfassers ,aufgeklärt' ist“.

${ }_{23}$ "Weltschande, die dem deutschen Volk droht".

24 ",jetzt in Deutschland [...] in Gang gebrachte Tötungsmaschinerie“.

25 ",eine Tötungsmaschinerie an den Deutschen angesetzt ist".

26 "die Deutschen geistig und geschichtlich auszulöschen. Man mache sich nichts vor. Ein alter Geist der Rache geht um die Erde“.
} 
of the coming great fascism (Großfaschismus) that is called democracy in America and Rus$\mathrm{sia}^{27}(249)$.

\section{Media and Technology}

Heidegger sees a world conspiracy at play. He asks in 1946: "How much long may the haste of calculation (Verrechnen) dominate? Or is it even still in the process of arranging itself as the law of machination (Machenschaft)?"28 (142). In 1948, Heidegger specifies the character of this machination as involving culture, technology, and Jewish religion: "Also culture is like the cultural consciousness that is given by it part of history, i.e. of subjectivity. It, culture namely, is grounded in the essence of technology as the instituting machination of squalidness (Verwahrlosung). The modern systems of total dictatorship originate from JewishChristian monotheism"29 (438). This passage is a form of religiously motivated anti-Semitism: Heidegger blames the Jews for what he sees as the decline he associates with modern technology and culture. One can find such an anti-Semitic passage in Heidegger's notes in 1948 just like in a letter from 1916, when the 27 year old wrote to his wife Elfride: "Our culture and universities' Jewification (Verjudung) is certainly frightening and I think the German race should still put about so much inner strength to lift itself up"30 (Heidegger 2005, 51). There are continuities in Heidegger's thought.

When speaking of domination or dictatorship in the years after the end of the Second World War covered in the Black Notebooks' fourth volume, Heidegger typically means modern media and modern technology. So in 1946 he for example writes about "the public's dictatorship by the domination of the "newspaper"'31. In 1946/1947 he says that technology has since 350 years meant the "destruction of being and human essence" ${ }^{32}$ (251). In 1948, Heidegger writes that "the domination by public opinion is already so dictatorial"33 (460) and he speaks of "the technical organisation of the public's Total Domination"34 (460), "the public's dictatorship today and its instruments" ${ }^{35}$ (509). Such passages give an idea of what he most likely meant when describing modern systems of total dictatorship that originated from Jewish-Christian monotheism.

The Black Notebooks' fourth volume shows that Heidegger in the years 1942-1948 saw a world conspiracy at play that he identified with Jews, modern technology, modern media, socialism, and democracy. He wrote down such thoughts also in 1948, just one year before he gave some of the talks that prepared his second most widely read book The Question Concerning Technology and Other Essays (Heidegger 1977) that was published in German in 1953 as Die Technik und die Kehre (Heidegger 1953).

In one of these preparatory talks that Heidegger held on December $1^{\text {st }}, 1949$, in Bremen (Heidegger 1953, 3), he made the infamous remark that agriculture "is now a motorized (motorisierte) food industry, in essence the same as the manufacturing of corpses in the gas chambers and extermination camps, the same as the blockade and starvation of the country-

\footnotetext{
27 „Die Antifaschisten sind die niedrigsten Sklaven des kommenden Großfaschismus, der sich in Amerika und Rußland Demokratie nennt".

${ }_{28}$ „Wie lang noch mag die Hast des Verrechnens herrschen? Oder ist sie gar erst dabei, sich als Gesetz der Machenschaft einzurichten?"

${ }_{29}$ „Auch die Kultur gehört, wie das mit inr gegebene Kulturbewußtsein zur Historie, d.h. zur Subjektivität. Sie gründet, die Kultur nämlich, im Wesen der Technik als der sich einrichtenden Machenschaft der Verwahrlosung. Die modernen Systeme der totalen Diktatur entstammen dem jüdisch-christlichen Monotheismus“.

${ }^{30}$ German original: „Die Verjudung unserer Kultur u. Universitäten ist allerdings schreckerregend u. ich meine die deutsche Rasse sollte noch soviel innere Kraft aufbringen um in die Höhe zu kommen“.

31 "Diktatur der Öffentlichkeit durch die Herrschaft der ,Zeitung'“.

32 "Zerstörung des Seyns und Menschenwesens".

33 "die Herrschaft der öffentlichen Meinung ist schon so diktatorisch".

34 ",technischen Organisation der Totalen Herrschaft der Öffentlichkeit“.

35 "die heutige Diktatur der Öffentlichkeit und ihr Instrumentarium“.
} 
side, the same as the production of the hydrogen bombs"36 (translation cited in: Farías 1989, 287) (for a discussion see Fuchs 2015, 71-73).

In The Question Concerning Technology, Heidegger (1977) terms modern technology das Ge-stell (the Enframing), by which he means "that challenging claim which gathers man thither to order" (19). The Ge-stell is an instrumental form of revealing. Modern technology as the Ge-stell would be associated with the exact sciences, mathematics, and modern physics (21) that have an instrumentalist worldview and believe in the calculability of the world.

The Black Notebooks' fourth volume illuminates that in the year before Heidegger gave the first preparatory talks for the Question Concerning Technology, he continued to hold a right-wing worldview that associates technology with a world conspiracy. Heidegger's main work on technology just like his other writings lacks an analysis and critique of the modern political economy of capitalism that frames and shapes modern technology's design and use. Heidegger instead believed in a world conspiracy whose main manifestation was for him modern technology. The Question Concerning Technology is grounded in Heidegger's rightwing ideology, which makes it incomprehensible why many analysts and theorists of technology, including many Internet and media scholars, positively reference this work. The right time to say goodbye to Heidegger's works and his analysis of technology has long come. The Black Notebooks' fourth volume and the right-wing worldview it reveals for the years 1942-1948 reinforce this judgement. Heidegger and the critical theory of society, the media and technology are irreconcilable. Such a theory can in contrast in a feasible manner be grounded in Karl Marx's dialectic of technology, Georg Lukács' notion of reification, Max Horkheimer and Theodor W. Adorno's concept of instrumental reason, and Herbert Marcuse's category of technological rationality.

\section{References}

Augstein, Rudolf et al. 1987. „Historikerstreit": Die Dokumentation der Kontroverse um die Einzigartigkeit der nationalsozialistischen Judenvernichtung. München: Piper.

Farías, Victor. 1989. Heidegger and Nazism. Philadelphia, PA: Temple University Press.

Fuchs, Christian. 2015. Martin-Heidegger's Anti-Semitism: Philosophy of Technology and the Media in the Light of the "Black Notebooks". Implications for the Reception of Heidegger in Media and Communication Studies. tripleC: Communication, Capitalism \& Critique 13 (1): 55-78.

Heidegger, Martin. 2015. Anmerkungen I-V (Schwarze Hefte 1942-1948). Gesamtausgabe, Band 97. Frankfurt am Main: Klostermann.

Heidegger, Martin. 2010. Being and Time. Translated by Joan Stambaugh. Albany, NY: State University of New York Press. Revised edition.

Heidegger, Martin. 2005. „Mein liebes Seelchen!“ Briefe Martin Heideggers an seine Frau Elfride 1915-1970. München: btb.

Heidegger, Martin. 1994. Gesamtausgabe, Band 79: Bremer und Freiburger Vorträge. Frankfurt am Main: Klostermann.

Heidegger, Martin. 1977. The Question Concerning Technology and other Essays. New York: Harper. Heidegger, Martin. 1953. Die Technik und die Kehre. Stuttgart: Klett-Cotta.

Heidegger, Martin. 1949. Über den Humanismus. Frankfurt am Main: Klostermann.

Nolte, Ernst. 1988. Eine Höhepunkt der Heidegger-Kritik? Victor Farías' Buch "Heidegger et le Nazisme". Historische Zeitschrift 247 (1): 95-114.

Trawny, Peter. 2014. Heidegger und der Mythos der jüdischen Weltverschwörung. Frankfurt am Main: Klostermann.

\section{About the Author}

\section{Christian Fuchs}

Christian Fuchs is a professor at the University of Westminster's Communication and Media Research Institute (CAMRI). He is editor of tripleC: Communication, Capitalism \& Critique. His research focuses on critical theory, political economy of media, communication, culture and the Internet, and critical

\footnotetext{
${ }^{36}$ German original: „Ackerbau ist jetzt motorisierte Ernährungsindustrie, im Wesen das Selbe wie die Fabrikation von Leichen in Gaskammern und Vernichtungslagern, das Selbe wie die Blockade und Aushungerung von Ländern, das Selbe wie die Fabrikation von Wasserstoffbomben" (Heidegger 1994, 27).
} 
media sociology. His monographs include Culture and Economy in the Age of Social Media (2015), OccupyMedia! The Occupy Movement and Social Media in Crisis Capitalism (2014), Digital Labour and Karl Marx (2014), Social Media: A Critical Introduction (2014), Foundations of Critical Media and Information Studies (2011), Internet and Society: Social Theory in the Information Age (2008). http://fuchs.uti.at, @fuchschristian. 